African Research Review

An International Multidisciplinary Journal, Ethiopia

Vol. 9(3), Serial No. 38, July, 2015:1-10

ISSN 1994-9057 (Print) ISSN 2070-0083 (Online)

DOI: http://dx.doi.org/10.4314/afrrev.v9i3.1

\title{
Impact of Political Environment on Business Performance of Multinational Companies in Nigeria
}

\author{
Mark, John \\ Department of Management \\ Rivers State University of Science and Technology \\ Port Harcourt, Nigeria \\ \& \\ Nwaiwu, Johnson N. \\ Department of Accounting \\ University of Port Harcourt \\ Rivers State, Nigeria
}

\begin{abstract}
This study investigated the impact of political environment on business performance of multinational companies in Nigeria. To achieve this purpose, a review of extant literature was made which was supported by hypothesis. The population of this study consists of quoted manufacturing companies in Nigeria. About twenty-seven (27) of such companies were identified and the necessary data were sourced from the Nigerian Stock Exchange Fact Book of 2012 and the World Development Indicators of World Bank Group. Political environment was measured as the degree of political stability and absence of violence while business performance was measured by the profitability of the companies for the period 1999-2013. Our findings showed that political environment has a negative significant impact on business performance of multinational companies in Nigeria. Based on the above, we suggest that the Nigerian government should avoid frequent changes in government policies and programmes,
\end{abstract}

Copyright (C) IAARR, 2015: www.afrrevjo.net

Indexed African Journals Online: www.ajol.info 
and ensure stability of democratic institutions and political integration. These are necessary to make the political terrain stable and out of violence for business growth and development.

Key words: Political environment, business performance, multinational companies.

\section{Introduction}

Business performance is the effort expended by a business firm in achieving its objectives of customer satisfaction, employee satisfaction, societal satisfaction, and ultimately profitability. Several studies such as Richard, Devinney, George and Johnson (2009), and Ibeto (2011), have shown that the effort expended by multinational business managers in achieving their goal in Nigeria has not been very successful. Richards et al (2009), maintain that the successful performance of multinational companies depends to a great extent on the political environment of the host country. According to these scholars, political environment refers to forces and issues emanating from the political decisions of government, which are capable of altering the expected outcome and value of a given economic action, by changing the probability of achieving business objectives. Ibeto (2011) described the political environment as factors arising from changes in government policies and programmes, which influence the ability of economic entities in achieving their goal.

The multinational business managers in Nigeria operates in a dynamic political environment characterized by risks of multiple taxation, currency devaluation, inflation, repatriation, expropriation, confiscation, campaigns against foreign goods, mandatory labour benefit legislation, kidnapping, terrorism, and civil wars (Griffen, 2005). Actions taken by government such as regulatory, legal framework, and political changes may decrease business income and acts as barriers to foreign investment.

Although it has been established that the political environment has a link with business performance, there seems to be inadequate literature and empirical evidence in Nigeria that relate the political environment to the performance of multinational companies. An attempt to investigate this relationship and expand the frontier of knowledge in this area of study led to the hypothesis that political environment has no significant relationship with business performance of multinational companies in Nigeria.

\section{Literature Review}

Not only that the political environment poses direct risks to firms, but politics is also component of other external risks. Ibeto (2011) posit that regulatory changes have the potential to promote or inhibit market competition, social risks often have political bases and responses, and political mismanagement can turn natural or human-made events into catastrophes. Moreover, the political environment is often 
perceived to be outside of management's control, making it difficult to define, predict, and align with objectives. Given the complexity of these issues, it is no wonder that corporations often fail to address issues of political environment in a systematic way. Multinational companies are grappling with political issues that sometimes surprise even the most experienced (Auster \& Choo, 1993).

For multinational companies, political risk emanating from the political environment refers to the risk that a host country will make political decisions that will prove to have adverse effects on the multinational's profits and/or goals. Adverse political actions can range from very detrimental, such as widespread destruction due to revolution, to those of a more financial nature, such as the creation of laws that prevent the movement of capital (Griffen, 2005). Generally, there are two types of political risk, risk and micro risk. Macro risk refers to adverse actions that will affect all foreign firms, such as expropriation or insurrection, whereas micro risk refers to adverse actions that will only affect a certain industrial sector or business, such as corruption and prejudicial actions against companies from foreign countries. Regardless of the type of political risk that a multinational corporation faces, companies usually will end up losing a lot of money if they are unprepared for these adverse situations. For example, after Fidel Castro's government took control of Cuba in 1959, hundreds of millions of dollars 'worth of American-owned assets and companies were expropriated. Unfortunately, most, if not all, of these American companies had no recourse for getting the money back (Andoh, 2007).

According to Walter (2014), the implication of political environment to a business is that the risk emanating from it is a measure of likelihood that political events may complicate its pursuit of earnings through direct impacts (such as taxes or fees) or indirect impacts (such as opportunity cost forgone). As a result, political risk is similar to an expected value such that the likelihood of a political event occurring may reduce the desirability of that investment by reducing its anticipated returns.

More so, there are political risks or events arising from nongovernmental actions, factors that are outside the government responsibility. There are wars, revolution, coup d'etat, terrorism, strikes, extortion, and kidnappings (Andoh, 2007). They all derived from some unstable social situation, with population frustration and intolerance. All these risks can generate violence, directed towards firms' property and employees. There may also be the case of externally induced financial constraints and externally imposed limits on imports or exports, especially in case of embargoes or any economic sanctions against the host country.

Political risks induced by the government constitute some laws directed against foreign firms. Some government-induced risks are very drastic. There are expropriation, confiscation and domestication (Auster \& Choo, 1993). According to Limna (2012), expropriation is the seizure of foreign assets by a government with 
payment of compensation to the owners. In other terms, it is involuntary transfer of property, with compensation, from a privately owned firm to a host country government. Expropriation may generate some funds for the owners. However, procedures to get paid from the government are sometimes protracted and the final amount remains low. Furthermore, if no compensation is paid, conflicts may erupt between the host country and the country of the expropriated firm. For instance, the relations between U.S. and Cuba acknowledge such situation, since Cuba does not offer compensation to U.S. firms that have their assets sized. Also, expropriation can refrain other companies from investing in the concerned country (Auster \& Choo, 1993).

Confiscation is another type of ownership risk similar to expropriation, except compensation. It is involuntary transfer of property, no compensation, from a privately owned firm to a host country government (Limna, 2012). In confiscation, firms do not receive any funds from government and therefore, it represents a more risky situation for foreign firms. Some industries are more vulnerable to confiscation than others because of their importance to the host countries and their lack of ability to shift operations. Sectors such as mining, energy, public utilities, and banking have been targets of such government actions.

Domestication offers to governments a subtle control over the foreign investments. Limna (2012) stated that domestication involves a partial ownership transfer and companies are urged to prioritize local production and to retain a large share of the profit within the country. Domestication can negatively impact the international business manager's activities, as well as that of the entire firm. For example, if foreign companies are forced to hire nationals as managers, poor cooperation and communication can result. If domestication was imposed within a short time span, poorly trained and inexperienced local managers would head the firm operations with possible loss of profits.

Other government actions-related risks are less dangerous but more common such as boycott and sabotage (Griffen, 2005). When facing shortage of foreign currency, government, sometimes, attempts to control the movement of capital in and out of the country. Often, exchange controls are levied selectively against certain products or companies. Exchange controls limit importation of goods so that firms might be confronted with difficulties in their regular transactions. Severe restrictions on import can be a motive for foreign corporation to shut down. There may also be a raise in tax rate applied to foreign investors in order to control them and their capital.

Government may also implement a price control system. Such control uses to derive from a sensitive political situation. For example, social pressure may result in a kind of price standardization for particular sectors like food, transportation, fuel, and 
healthcare. Political risks like arms conflicts, insurrection may affect all firms in the country equally. For that reason they are called macro political risks. Unlike, nationalization, strikes, expropriation may affect only a handful and specific firm, and they are named micro political risks (Griffen, 2005; Andoh, 2007).

Some negative effects of the political environment on multinational firms are summarized in the following table.

Table 1.Negative effects of the political environment on multinational firms

\begin{tabular}{|l|l|}
\hline Types & Impact on Firms \\
\hline Expropriation & Loss of future profits \\
\hline Confiscation & Loss of assets \\
\cline { 2 - 2 } & Loss of future profits \\
\hline Campaigns against foreign goods & Loss of sales \\
\hline Mandatory labor benefits legislation & $\begin{array}{l}\text { Increased costs of public relations efforts to } \\
\text { improve public image }\end{array}$ \\
\hline Kidnappings, terrorists threats, and & Increased operating costs \\
\hline other forms of violence & Disrupted production \\
\hline Increased security costs \\
\hline Civil wars & Increased managerial costs \\
\hline & Lower productivity \\
\hline & Destruction of property \\
\hline & Lost sales \\
\hline & Disruption of production \\
\hline & Lower productivity \\
\hline
\end{tabular}

Copyright $\odot$ IAARR, 2015: www.afrrevjo.net Indexed African Journals Online: www.ajol.info 
AFRREV, VOL. 9(3), S/NO 38, JULY, 2015

\begin{tabular}{|l|l|}
\hline Inflation & Higher operating costs \\
\hline Repatriation & Inability to transfer funds freely \\
\hline Currency devaluations & Reduced value of repatriated earnings \\
\hline Increased taxation & Lower after-tax profits \\
\hline
\end{tabular}

Source: Griffin, R.W (2005). International business, page 73

A low level of adverse effect of the political environment in a given country does not necessarily correspond to a high degree of political freedom. Indeed, some of the more stable states are also the most authoritarian. Long-term assessments of political risk must account for the danger that a politically oppressive environment is only stable as long as top-down control is maintained and citizens prevented from a free exchange of ideas and goods with the outside world (Phung, 2009).

There are two fundamental ways in which the assessment of the political environment improves global business performance: protecting new and existing global investments and operations, and capitalizing on opportunities resulting from political change (Phung, 2009).

It is our belief that by establishing a systematic approach to political risk management, multinational companies can drive business performance improvement.

\section{Business Performance}

Business Performance (BP) has been taught with many conflicting definitions and it is not a new phenomenon among the academics and the industrialists. Business performance has been a source of influence to the actions taking by firms and the degree to which a business realises its goals as well as its stated objectives through the strategies and policies of the business (Folan \& Browne, 2005). The idea of business performance is hanged on the position or premise that it is a combination of productive assets made up of human, physical, and capital resources, for the major reason of fulfilling a dream, vision or accomplishing a shared purpose (Barney, 2002; Carton \& Hofer, 2006). 
Business performance is a measure of how a manager efficiently and effectively utilizes the resources of the firm to accomplish its goals as well as satisfying all the stakeholders (Jones \& George, 2009). It is the real output measured against the intended or expected output. It is viewed as a term that is made up of three major areas of firm outcomes and these three areas are: financial performance that is made up of profits, return on assets (ROA), return on investment (ROI); product market performance such as sales revenue and market share; and shareholders return such as total shareholder return (TSR) and economic value added (EVA).

According to Selden and Sowa (2004) business performance is what is designed to assume that a firm accomplishes certain goals that are both specified intrinsically and implicitly. Perrow (1961) distinguishes between two kinds of organisational goals, official goals which are the general purposes of the organisation's founders and leaders, while the operative goals designates the end sought through the actual operating policies, the modifications and subversions of these ends by personnel in decision making positions and by the forces of pressure from the external environment. However, Kast \& Rosenzwig (1985) argued that performance is a function of ability, effort and opportunity. Ability is dependent upon knowledge and skills and technological capabilities that provide an indication of range of possible performance. Effort is a function of needs, goal- expectation and rewards and it depends on the degree to which individuals and/or groups are motivated to aspirant effort. Opportunity must be provided by the managers for individual's ability and effort to be used in ways that will result in the achievement of goals. In a nutshell, business performance is an approach used in assessing the progress made toward goals, identifying and adjusting factors that limit the progress of the firm in a competitive environment.

\section{Methodology}

The population of this study consists of quoted manufacturing companies in Nigeria. About twenty-seven (27) of such companies were identified and the necessary data were sourced from the Nigerian Stock Exchange Fact Book of 2012 and the World Development Indicators of World Bank Group. Political environment was measured as the degree of political stability and absence of violence while business performance was measured by the profitability of the companies for the period 1999-2013. The model framework designed for this study is shown thus:

$\mathrm{BUP}=\mathrm{f}\{\alpha 0 \log +\beta 1 \log \mathrm{POIS}+\beta 2 \log \mathrm{POV}\}$

Where;

BUP $=$ Business Performance

POIS $=$ Political Instability 
AFRREV, VOL. 9(3), S/NO 38, JULY, 2015

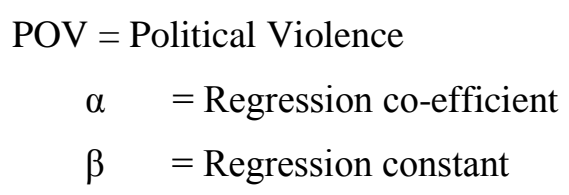

The data generated for this study were analyzed using the regression model, which was computed with the aid of the Statistical Package for Social Sciences (SPSS) version 17.

\section{Analysis and Results}

In measuring the impact of political environment on business performance, data on political instability and violence were correlated with data on profitability, and the results obtained were presented in the table below.

Table 1: Relationship between political environment and business performance

\begin{tabular}{|l|l|}
\hline Statistical Variables & Values \\
\hline Regression Constant $(\alpha)$ & 24711.032 \\
Regression Co-efficient $(\beta)$ & -0.203 \\
Correlation Co-efficient (R) & -0.736 \\
Co-efficient of Determination (R2) & 0.542 \\
P-value & 0.028 \\
t-statistics & 2.001 \\
\hline
\end{tabular}

Source: SPSS Version 17 Windows Output

The result presented in the table above revealed a correlation co-efficient of 0.736, which is close to one from the negative side. This indicates a strong negative association between political environment and business performance of multinational companies in Nigeria. For $1 \%$ change in political instability and violence, business performance will reduce by $20.3 \%$. The co-efficient of determination of 0.542 suggests that about $54.2 \%$ decline in business performance is attributable to political instability and violence. The p-value (0.028) and the t-statistics (2.001) indicate a significant relationship of the variables. Therefore, the null hypothesis is rejected. This implies that the political environment has a significant impact on business performance of multinational companies in Nigeria. 


\section{Conclusion and Recommendations}

The result of our analysis shows that political environment has a significant impact on business performance of multinational companies. The Nigerian political environment is characterized by frequent changes in government policies and programmes thereby negatively affecting corporate long-term planning. This is attributable to party politics with threats of conflict and wars, growing levels of crime and terrorism, kidnapping, bomb blast, among others thereby hindering business patronage and scaring away foreign investors from the country. Multinational companies can gain significant benefits from managing the political environment and its associated risks and ignore the environment at their peril. Effective management of political environment can enable companies to tap new revenue streams through access to markets and joint ventures that, without careful management, might seem too risky. Clear identification, measurement and management of risk can facilitate organizational buy-in for growth strategies that target emerging markets and "frontier" markets, while improving the performance of existing businesses. Based on the above, we suggest that the Nigerian government should avoid frequent changes in government policies and programmes, and ensure stability of democratic institutions and political integration. These are necessary to make the political terrain stable and out of violence for business growth and development.

\section{References}

Auster, C. \& Choo, C. W. (1993). Environmental scanning by CEOs in two Canadian industries: Journal of the American Society for Information Science and Technology, 44(4), 194-203.

Barney, J. B. (2002). Gaining and sustaining competitive advantage: Upper Saddle River, New Jersey, Pearson Education.

Andoh, C. H. (2007). Competing effectively: environmental scanning, competitive strategy and organisational performance in small manufacturing firms. Journal of Small Business Management, 38(1), 27-47.

Carton, R. B. \& Hofer, C.W., (2006). Measuring Organisational Performance: Metrics for Entrepreneurship and Strategic Management Research. MA, USA: Edward Elgar, Northampton,

Folan, P. \& Browne, J. (2005). A review of performance measurement: Towards performance management. Computers in Industry, 56, 663-680. 
Griffin, R.W. (2005). International business. New York: Mc Graw-Hill Inc.

Jones, G. R. \& George, J. M. (2009). Contemporary management: 6th International British Journal of Arts and Social Sciences, New York, USA: McGraw-Hill.

Kast, F. E. \& Rosenzwig, J. E. (1985). Organisation and management: a systems and contingency approach, McGraw-Hill.

Limna, M. D. (2012). Environmental scanning behaviour in a transitional economy: Evidence from Russia. Academy of Management Journal, 43(3), 403-42.

Phung, T. (2009). The analysis of goals in complex organizations. American Sociological Review, 26, 854-866.

Richard, P. J., Devinney, T.M., George, S. Y. \& Johnson, G. (2009). Measuring organisational performance: Towards Methodological Best Practices. Journal of Management, 35(3), 718-804.

Selden, S. C. \& Sowa, J. E. (2004). Testing a multi-dimensional model of organisational performance: prospects and problems: Journal of Public Administration Research and Theory, 14(3), 395-416. 